\title{
Nitrogen sources on yield, mineral nutrition and bromatology of Cyclanthera pedata
}

\author{
Samuel V Valadares ${ }^{1} \mathbb{D}$; Rafael V Valadares ${ }^{2} \mathbb{D}$; Candido A Costa ${ }^{3} \mathbb{D}$; Ernane R Martins ${ }^{3} \mathbb{D}$; Luiz A Fernandes $^{3} \mathbb{D}$
}

${ }^{1}$ Universidade Federal de Viçosa (UFV), Viçosa-MG, Brasil; samuel.valadares@ufv.br; ${ }^{2}$ Universidade Estadual de Campinas (NIPE, UNICAMP), Campinas-SP, Brasil; rafaelvvaladares@gmail.com; ${ }^{3}$ Universidade Federal de Minas Gerais (UFMG), Montes Claros-MG, Brasil; candido-costa@ica.ufmg.br; ernane.ufmg@gmail.com; luizmcmg@gmail.com

\begin{abstract}
Caygua fruits (Cyclanthera pedata) are used both in cooking and for medicinal purposes. However, few studies on this species, considered a non-conventional vegetable, can be found in literature. This study aimed to assess the responses of caygua crop to green manure and mineral nitrogen fertilization, in relation to marketable fruit productivity, nutrient content in leaves and fruits and bromatological composition. The study was carried out in a randomized block design with four treatments and five replicates: 1) control (without nitrogen); 2) $60 \mathrm{~kg} \mathrm{ha}^{-1}$ nitrogen (urea form); 3 ) green manuring using Cajanus cajans and 4) green manuring using Crotalaria juncea. The plots consisted of three caygua lines with four plants per line (spacing $2 \times 1 \mathrm{~m}$ ). In the treatments using green manure, three lines of these respective legumes were cultivated. We evaluated marketable fruit productivity, nutrient contents in fruits and leaves and bromatological composition of the fruits. Production of caygua fruits was higher in the treatment consisting of urea application $\left(23.6 \mathrm{t} \mathrm{ha}^{-1}\right)$, followed by Crotalaria juncea $\left(15.6 \mathrm{t} \mathrm{ha}^{-1}\right)$, Cajanus cajans $(14.8 \mathrm{t}$ $\left.\mathrm{ha}^{-1}\right)$ and control $\left(9.2 \mathrm{t} \mathrm{ha}^{-1}\right)$. Treatments did not influence the nutrient contents in fruits and leaves and the bromatological composition. However, in relation to higher productivity, the amounts of nutrients absorbed by plants and accumulated in fruits were higher in treatments using mineral fertilization due to the higher yield. The bromatological analysis of fruits showed considerable contents of crude protein and ether extract, highlighting the potential of this species to human diet.
\end{abstract}

Keywords: Cyclanthera pedata, green manuring, non-conventional vegetable, medicinal plant.

\section{RESUMO}

Fontes de nitrogênio na produtividade, nutrição mineral e bromatologia do maxixe do reino

Os frutos do maxixe do reino (Cyclanthera pedata) são utilizados tanto na culinária quanto para fins medicinais. No entanto, há poucos estudos sobre essa espécie, considerada cucurbitácea não convencional. Esta pesquisa teve por objetivo estudar as respostas da cultura do maxixe do reino à adubação verde e mineral com nitrogênio na forma de ureia, quanto à produtividade de frutos comerciais, teor de nutrientes nas folhas e frutos e composição bromatológica. O experimento foi conduzido em delineamento de blocos casualizados com quatro tratamentos e cinco repetições: 1) controle (sem nitrogênio); 2) $60 \mathrm{~kg} \mathrm{ha}^{-1}$ de nitrogênio na forma de ureia; 3) adubação verde com Cajanus cajans e 4) adubação verde com Crotalaria juncea. As parcelas foram constituídas por três linhas de maxixe do reino com quatro plantas por linha, no espaçamento de $2 \mathrm{x} 1 \mathrm{~m}$. Nos tratamentos com adubo verde foram cultivadas três linhas das respectivas leguminosas. As variáveis avaliadas foram produtividade de frutos comerciais, teores de nutrientes nos frutos e nas folhas e composição bromatológica dos frutos. A produção de frutos do maxixe do reino foi maior no tratamento com aplicação de ureia $\left(23,6 \mathrm{t} \mathrm{ha}^{-1}\right)$, seguida pela Crotalaria juncea $\left(15,6 \mathrm{t} \mathrm{ha}^{-1}\right)$, Cajanus cajans $\left(14,8 \mathrm{t} \mathrm{ha}^{-1}\right)$ e testemunha $\left(9,2 \mathrm{tha}^{-1}\right)$. Os tratamentos não influenciaram nos teores de nutrientes nos frutos e folhas e a composição bromatológicas dos frutos. No entanto, em função da maior produtividade, as quantidades de nutrientes absorvidas pelas plantas e acumuladas nos frutos foram maiores nos tratamentos com adubação mineral. A análise bromatológica dos frutos revelou consideráveis teores de proteína bruta e extrato etéreo, ressaltando o potencial desta espécie para a dieta alimentar humana.

Palavras chave: Cyclanthera pedata, adubação verde, olerícola não convencional, planta medicinal.

\section{Received on August 12, 2019; accepted on February 20, 2020}

$\mathrm{C}$ aygua (Cyclanthera pedata) is a non-conventional vegetable belonging to Cucurbitaceae family, with indeterminate growth habit, oblong fruits, simple and palminerous leaves and unisexual flowers at the leaf axilla (Macchia et al., 2009). Caygua fruits are dedicated exclusively to human consumption, in food or in the medicine production (Costa et al., 2008; Macchia et al., 2009). This species is found growing under spontaneous or subspontaneous conditions, mainly in Bolivia, Chile, Colômbia, Argentina and
Peru (Fernandes et al., 2005).

Deep soils with $\mathrm{pH}$ close to neutrality are considered suitable for the crop growth. The cycle is approximately 100 days counting from the crop establishment to first harvest, continuing for another 45 to 60 days (Macchia et 
al., 2009).

In Brazil, in the Northern Region of Minas Gerais State, caygua plants are especially grown by family farmers, where the fruits are traded in local markets (Fernandes et al., 2005; Costa et al., 2008). According to these authors, production areas are restricted to more fertile soils and their productivities are related, among other factors, to the crop nutritional management. Due to these peculiarities of producers and consumers, no records in statistical yearbooks on the Brazilian production of caygua fruits can be found (Fernandes et al., 2013).

Nitrogen is the most required nutrient by caygua plants, and is one of the most limiting growth factors for this crop. So, developing alternative nutritional management techniques related to nitrogen supply is necessary to produce this vegetable on small-scale farms (Fernandes et al., 2005).

The use of green manures, with nitrogen fixing species, is widely recommended for providing nitrogenrich plant residues to replace or complement mineral fertilization (Duarte et al., 2013; Zhang et al., 2017; Sarmento et al., 2019). Moreover, this practice contributes to the reduction of greenhouse-gas emissions by agricultural activities (Forte et al., 2017; Fungo et al., 2019).

This study aimed to assess the responses of caygua plants to green manure and mineral fertilizations, in relation to marketable fruit productivity, nutrient content in leaves and fruits and bromatological composition.

\section{MATERIAL AND METHODS}

The experiment was carried out in the field, from February to October, 2010, at Instituto de Ciências Agrárias of Universidade Federal de Minas Gerais, Montes Claros campus (16 $40^{\circ}$ '51"S, $43^{\circ} 50^{\prime} 22^{\prime \prime} \mathrm{W}, 650 \mathrm{~m}$ altitude). The regional climate, according to Köppen, is Aw, tropical savanna, dry winter, with rainfall concentration in summer (Alvares et al., 2013).

The soil in the experimental area is an Oxisol, showing the following characteristics: $\mathrm{pH}$, water $=4.5 ; \mathrm{P}=1.0$ $\mathrm{mg} \mathrm{dm}{ }^{-3} ; \mathrm{Ca}=2.1 \mathrm{mmolc} \mathrm{dm}^{-3} ; \mathrm{Mg}=0.8$ mmolc dm ${ }^{-3} ; \mathrm{K}=0.5 \mathrm{mmolc} \mathrm{dm}^{-3} ; \mathrm{Al}=$ $23 \mathrm{mmolc} \mathrm{dm}^{-3} ; \mathrm{H}+\mathrm{Al}=110 \mathrm{mmolc} \mathrm{dm}^{-3}$; $\mathrm{Zn}=0.3 \mathrm{mg} \mathrm{dm}^{-3} ; \mathrm{Mn}=2.2 \mathrm{mg} \mathrm{dm}^{-3}$; $\mathrm{Fe}=8.3 \mathrm{mg} \mathrm{dm}^{-3} ; \mathrm{Cu}=0.1 \mathrm{mg} \mathrm{dm}^{-3}$; $\mathrm{B}=0.1 \mathrm{mg} \mathrm{dm}^{-3}$; organic matter $=18 \mathrm{~g}$ $\mathrm{kg}^{-1}$; sand $=500 \mathrm{~g} \mathrm{~kg}^{-1} ;$ silt $=80 \mathrm{~g} \mathrm{~kg}^{-1}$ and clay $=420 \mathrm{~g} \mathrm{~kg}^{-1}$. The soil analysis was performed following the methods described by Embrapa (1997).

The experimental design was randomized blocks, with four treatments and five replicates. The treatments consisted of: 1) control (without nitrogen); 2) $60 \mathrm{~kg} \mathrm{ha}^{-1}$ nitrogen (urea form); 3 ) intercropped with pigeon-pea (Cajanus cajans) cv. IAPAR 43 Aratã) and 4) intercropped with crotalaria (Crotalaria juncea).

The plots consisted of three lines of caygua with four plants per line, conducted in vertical trellis system, spacing $2 \mathrm{~m}$ between lines and $1 \mathrm{~m}$ between plants. In the treatments using green manure, three lines of these legumes were grown in spacing $0.5 \mathrm{~m}$ between lines. In the plots using urea, weeding was done manually between lines. The useful plot consisted of two central plants in the central line.

Three months before implementing the experiment, the soil was plowed and harrowed. Furrows were opened in 30-cm-deep lines and liming was performed using dolomitic limestone, in order to reach $60 \%$ of base saturation (Fernandes et al., 2005). The basic fertilization consisted of applying $20 \mathrm{~L}$ $\mathrm{m}^{-1}$ cattle manure into sowing furrows. Furthermore, 30 days before planting, $30 \mathrm{~g} \mathrm{~m}^{-1}$ of $\mathrm{P}_{2} \mathrm{O}_{5}$ in the form of reactive phosphate rock, at planting, and $40 \mathrm{~g}$ $\mathrm{m}^{-1}$ of $\mathrm{K}_{2} \mathrm{O}$ were was applied in the form of potassium chloride, splitted in two applications, half at planting and half after 40 days. Analytical determinations of the cattle manure according to the methodology presented by Fermino et al. (2000) presented: $\mathrm{C} / \mathrm{N}=16.6$; total $\mathrm{N}=21 \mathrm{~g} \mathrm{~kg}^{-1} ; \mathrm{P}_{2} \mathrm{O}_{5}=9.8 \mathrm{~g} \mathrm{~kg}^{-1} ; \mathrm{K}_{2} \mathrm{O}=$ $10.6 \mathrm{~g} \mathrm{~kg}^{-1} ; \mathrm{CaO}=12.8 \mathrm{~g} \mathrm{~kg}^{-1} ; \mathrm{MgO}=6.5$ $\mathrm{g} \mathrm{kg}^{-1} ; \mathrm{S}=0.1 \mathrm{~g} \mathrm{~kg}^{-1} ; \mathrm{B}=38 \mathrm{mg} \mathrm{kg}^{-1} ; \mathrm{Zn}=$ $84 \mathrm{mg} \mathrm{kg}^{-1} ; \mathrm{Fe}=15.3 \mathrm{~g} \mathrm{~kg}^{-1} ; \mathrm{Mn}=250$ $\mathrm{mg} \mathrm{kg}{ }^{-1} ; \mathrm{Cu}=36 \mathrm{mg} \mathrm{kg}^{-1}$ dry mass base.

The treatment using mineral fertilization was applied in three monthly applications of $20 \mathrm{~kg} \mathrm{ha}^{-1} \mathrm{~N}$ in urea form, beginning at planting. Green manure was sown continuously, at the same planting date of caygua plants, in furrows, spacing $50 \mathrm{~cm}$ from each other, thinning at 10 days after seedling emergence, keeping planting density of 30 plants per linear meter. Both green manures were cut and incorporated into soil when $50 \%$ of the plants started flowering, considering that the crotalaria was incorporated at 60 days and pigeon pea at 120 days after sowing.

During the trial period, two manual weedings were performed and complementary irrigation was carried out through drip system.

In order to analyze leaf nutrient contents, two mature leaves were collected from the middle third of each plant, one leaf on each side of the vertical trellis system and fruits were harvested manually when they reached commercial standard, approximately 12 $\mathrm{cm}$ long (2 harvests).

Fruits and leaves were oven dried until constant weight at $60^{\circ} \mathrm{C}$, and they were chemically analyzed considering $\mathrm{N}, \mathrm{P}, \mathrm{K}, \mathrm{Ca}, \mathrm{Mg}, \mathrm{S}, \mathrm{B}, \mathrm{Zn}, \mathrm{Fe}$ and $\mathrm{Mn}$ using the methodology proposed by Malavolta et al. (1997).

Samples consisting of 10 fruits per plot were randomly collected and analyzed considering the following bromatological characteristics: moisture, total dry matter, macro and micronutrients, crude protein, ether extract, ash and crude fiber.

All variables were submitted to variance analysis and treatment averages were compared using Tukey test at 5\% probability. SAEG statistical software, System for Statistical and Genetics Analyses was used (Ribeiro Júnior, 2001).

\section{RESULTS AND DISCUSSION}

Productivity of marketable caygua fruits was affected by the treatments (Figure 1), plant yield increased $156.52 \%$ with mineral fertilization when compared to the control treatment. Green manures intercropping treatments presented average productivities of marketable fruits 69.57 and $60.87 \%$ 
greater than the control, respectively for the treatments pigeon pea and crotolaria. These results are corroborated by Fernandes et al. (2005), who reported a high caygua crop $\mathrm{N}$ demand, considering $\mathrm{N}$ the most extracted nutrient by plants of this species.

In the present study, the maximum production of commercial caygua fruits was $23.6 \mathrm{t} \mathrm{ha}^{-1}$, obtained applying urea (Figure 1). This productivity corresponded to $72.8 \%$ of the maximum production obtained by other authors (Fernandes et al., 2013), under similar conditions.

The high capacity of nitrogen supply by green manures is associated with the capacity for biological $\mathrm{N}_{2}$ fixation resulting from the symbiosis between legumes and bacteria (Brito et al., 2011), as well as their indirect benefits for improving soil chemical, physical and biological properties (Duarte et al., 2013). On the other hand, it is also worth mentioning that the green manures grown intercropped may compete for growth resources with the main crop (Miyazawa et al., 2010; Valadares et al., 2012, 2016). This fact can help to explain the lowest productivity in the treatments which contained green manure compared with the treatment using mineral fertilizer (Figure 1).

In addition, the supply of $\mathrm{N}$ mineralized from the green manures biomass mismatched the periods of highest nutritional demand of the caygua plants. (Sharifi et al., 2009) considering that incorporation of crotalaria and pigeon pea was at 60 and 120 days, respectively, after planting.

Our results show that further studies on sowing of green manure in pre planting for this crop are necessary. Guedes et al. (2010) recommend legume planting for obtaining green manure with the necessary advance so that nitrogen mineralization coincides with the nutritional requirements of the main crop.

Future studies should also consider variations in green manure planting density in order to better meet the nutritional requirements of caygua fruits, as well as, other factors that affect $\mathrm{N}$ mineralization and the response of crops to these practices, such as soil, climate and plant species (Sharifi et al., 2009; Diniz et al., 2014).

In addition to making nitrogen available, green manures contribute positively to the root system of crops in intercropping or succession (Valadares et al., 2012, 2016). Miyazawa et al. (2010), studying the root systems of legume species intercropped with grasses, observed that both Crotalaria juncea and sorghum showed greater distribution of roots when compared to monoculture, showing complementarity in the exploitation of soil resources.

No significant differences for nutrient contents among treatments, both in fruits and leaves were verified in our study (Table 1). The absence of significant effects on the contents may be associated with the effects of nutrient dilution, since nitrogen is a nutrient that highly affects plant growth (Weih et al., 2011). In the treatment using urea, although the nutrient content in the plant is similar to that of the other treatments, fruit production was 2.58 , 1.51 and 1.78 times greater than the control treatments, green manure using pigeon pea and green manure with crotalaria, respectively (Figure 1). Thus, effects of applying $\mathrm{N}$ are associated with increases in macro and micronutrients accumulation in caygua fruits (Table 2).

We found no difference among treatments for the bromatological properties of caygua fruits (Table 3 ).

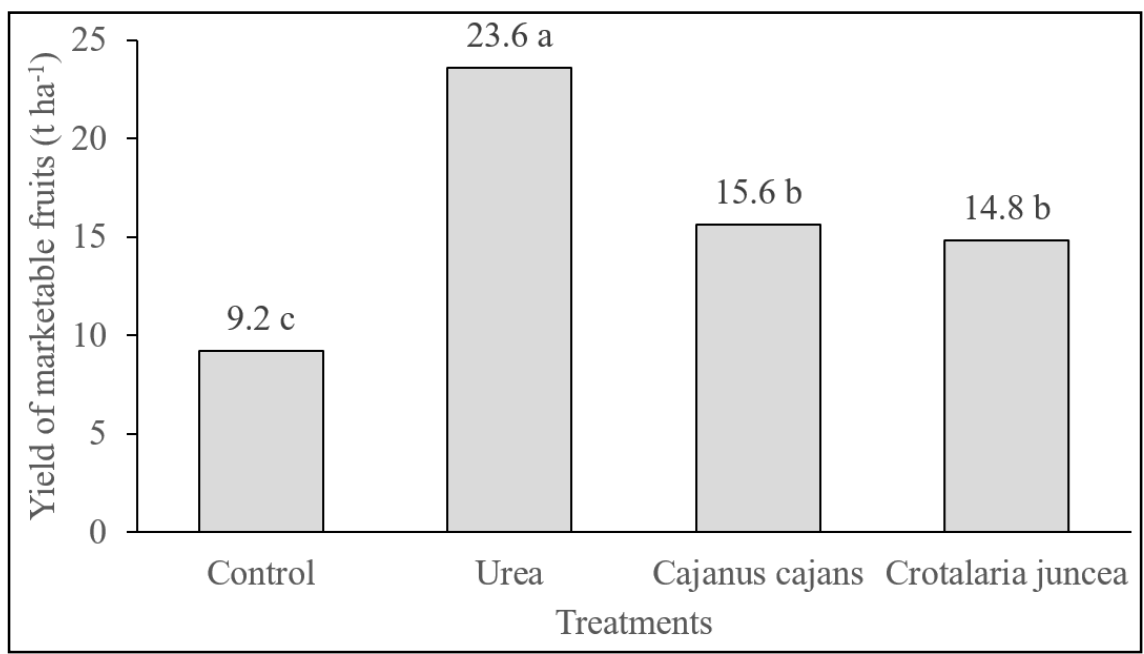

Figure 1. Marketable caygua fruit productivity in relation to nitrogen source (variation coefficient $8.6 \%$ ). Averages followed by same letters did not significantly differ, Tukey's test, 5\%. Montes Claros, ICA-UFMG, 2020.

Table 1. Nutrient contents in caygua fruits and leaves. Montes Claros, ICA-UFMG, 2020.

\begin{tabular}{lcccc}
\hline Nutrient & $\begin{array}{c}\text { Content in } \\
\text { fruits }\left(\mathbf{g ~ k g}^{-1}\right)\end{array}$ & $\begin{array}{c}\text { Variation } \\
\text { coefficient (\%) }\end{array}$ & $\begin{array}{c}\text { Content in } \\
\text { leaves }\left(\mathbf{g ~ k g}^{-1}\right)\end{array}$ & $\begin{array}{c}\text { Variation } \\
\text { coefficient (\%) }\end{array}$ \\
\hline $\mathrm{N}$ & 21.8 & 8.5 & 31.8 & 5.6 \\
$\mathrm{P}$ & 6.0 & 9.2 & 2.8 & 4.8 \\
$\mathrm{~K}$ & 38.4 & 7.3 & 25.3 & 6.8 \\
$\mathrm{Ca}$ & 4.2 & 5.8 & 31.4 & 6.4 \\
$\mathrm{Mg}$ & 2.1 & 9.4 & 5.1 & 8.2 \\
$\mathrm{~S}$ & 2.0 & 13.4 & 2.3 & 12.4 \\
\hline & $\mathbf{( m g ~ \mathbf { ~ g g } ^ { - 1 } )}$ & $\mathbf{( \% )}$ & $\mathbf{( m g ~ \mathbf { ~ g } ^ { - 1 } )}$ & $\mathbf{( \% )}$ \\
\hline $\mathrm{B}$ & 10.3 & 8.9 & 26.9 & 9.5 \\
$\mathrm{Zn}$ & 21.3 & 5.4 & 24.8 & 7.2 \\
$\mathrm{Fe}$ & 12.3 & 6.8 & 358.6 & 12.6 \\
$\mathrm{Mn}$ & 5.9 & 8.1 & 33.2 & 11.8 \\
\hline
\end{tabular}


These results show that even under lower nitrogen availability, such as in the control treatment, the fruits maintained their bromatological properties at the expense of production. On the other hand, considering dry mass production (Figure 1), the amount of protein produced per hectare corresponded to: control $\left(68.61 \mathrm{~kg} \mathrm{ha}^{-1}\right)$, pigeon pea $\left(117.37 \mathrm{~kg} \mathrm{ha}^{-1}\right)$, crotolaria $\left(99.9 \mathrm{~kg} \mathrm{ha}^{-1}\right)$ and urea $\left(163.05 \mathrm{~kg} \mathrm{ha}^{-1}\right)$.

Crude protein contents in caygua fruits were similar to the ones found in cucumber fruits (Cucumis anguria) (Lima et al., 2006), which also belongs to Cucurbitacea family. In addition to the potential benefits to human nutrition, caygua also presents therapeutic properties with anti-inflammatory, hypoglycemic and hypocholesterolemic action (Carbone et al., 2004).

Table 2. Nutrient accumulation in caygua fruits in relation to nitrogen sources. Montes Claros, ICA-UFMG, 2020.

\begin{tabular}{lrrrrc}
\hline \multirow{2}{*}{ Nutrient } & Control & \multicolumn{1}{c}{ Urea } & Pigeon pea & Crotalaria & $\begin{array}{c}\text { Variation } \\
\text { Coefficient (\%) }\end{array}$ \\
\cline { 2 - 5 }$\left(\mathbf{k g ~ h a}^{-1}\right)$ & & 7.6 \\
$\mathrm{~N}$ & $12.02 \mathrm{c}$ & $28.28 \mathrm{a}$ & $19.03 \mathrm{~b}$ & $16.46 \mathrm{~b}$ & 8.6 \\
$\mathrm{P}$ & $3.40 \mathrm{c}$ & $7.10 \mathrm{a}$ & $5.51 \mathrm{~b}$ & $4.72 \mathrm{~b}$ & 7.6 \\
$\mathrm{~K}$ & $21.49 \mathrm{c}$ & $45.59 \mathrm{a}$ & $33.70 \mathrm{~b}$ & $31.33 \mathrm{~b}$ & 7.2 \\
$\mathrm{Ca}$ & $2.31 \mathrm{c}$ & $4.99 \mathrm{a}$ & $3.82 \mathrm{~b}$ & $3.36 \mathrm{~b}$ & 9.4 \\
$\mathrm{Mg}$ & $1.15 \mathrm{c}$ & $2.44 \mathrm{a}$ & $1.96 \mathrm{~b}$ & $1.60 \mathrm{~b}$ & 12.4 \\
$\mathrm{~S}$ & $1.09 \mathrm{c}$ & $2.55 \mathrm{a}$ & $1.87 \mathrm{~b}$ & $1.52 \mathrm{~b}$ & $\mathbf{( \% )}$ \\
\hline \multicolumn{5}{c}{$\left(\mathbf{g ~ h a}^{-1}\right)$} \\
$\mathrm{B}$ & $5.95 \mathrm{c}$ & $11.42 \mathrm{a}$ & $8.63 \mathrm{~b}$ & $9.11 \mathrm{~b}$ & 6.5 \\
$\mathrm{Zn}$ & $11.96 \mathrm{c}$ & $23.63 \mathrm{a}$ & $20.63 \mathrm{~b}$ & $16.62 \mathrm{~b}$ & 7.9 \\
$\mathrm{Fe}$ & $6.86 \mathrm{c}$ & $14.09 \mathrm{a}$ & $10.58 \mathrm{~b}$ & $10.47 \mathrm{~b}$ & 10.4 \\
$\mathrm{Mn}$ & $3.34 \mathrm{c}$ & $6.88 \mathrm{a}$ & $5.25 \mathrm{~b}$ & $4.88 \mathrm{~b}$ & 11.3 \\
\hline
\end{tabular}

${ }^{1}$ Averages followed by same letters did not significantly differ, Tukey's test, $5 \%$.

Table 3. Bromatological parameters of caygua fruits. Montes Claros, ICA-UFMG, 2020.

\begin{tabular}{lcc}
\hline Properties & $\begin{array}{c}\text { Average values } \\
\text { (\%) }\end{array}$ & $\begin{array}{c}\text { Variation coefficient } \\
\text { (\%) }\end{array}$ \\
\hline Total moisture of fresh sample & 94.4 & 14.5 \\
Dry matter of fresh sample & 5.6 & 10.2 \\
Crude protein & 12.9 & 13.7 \\
Total moisture of dry sample & 9.1 & 12.6 \\
Total dry matter of dry sample & 90.9 & 15.8 \\
Ethereal extract (\% of dry matter) & 3.9 & 16.9 \\
Ashes (\% of dry matter) & 10.7 & 12.4 \\
Crude fiber (\% of dry matter) & 20.3 & 16.4 \\
\hline
\end{tabular}

Cooperation of the Coordination for the Improvement of Higher Education Personnel (CAPES/Brazil), by the Brazilian National Council for Scientific and Technological Development (CNPq/Brazil) and by the Foundation for Research Support of São Paulo (FAPESP) $\left(\mathrm{n}^{\circ} 2018 / 24707-0\right)$. The authors are grateful for the scholarships granted.

\section{REFERENCES}

ALVARES, CA; STAPE, JL; SENTELHAS, PC; GONÇALVES, JLM; SPAROVEK, G. 2013. Köppen's climate classification map for Brazil. Meteorologische Zeitschrift 22: 711-728.

BRITO, MMP; MURAOKA, T; SILVA, EC. 2011. Contribuição da fixação biológica de nitrogênio, fertilizante nitrogenado e nitrogênio do solo no desenvolvimento de feijão e caupi. Bragantia 70: 206-215.

CARBONE, V; MONTORO, P; TOMMASI, N; PIZZA, C. 2004. Analyzis of flavonoids from Cyclanthera pedata chromatography/ electrospray mass spectrometry. Journal of Pharmaceutical and Biomedical Analyzis 34: 295-304.

COSTA, CA, RAMOS, SJ, ALVES, DS, FERNANDES, LA, SAMPAIO, RA, MARTINS, ER. 2008. Nutrição mineral do mangarito num Latossolo Vermelho Amarelo. Horticultura Brasileira 26: 102-106.

DINIS, ER; VARGAS, TO; REREIRA, WD; GUEDES, AF; SANTOS RHS; PETERNELLI, LA. 2014. Decomposição e mineralização do nitrogênio proveniente do adubo verde Crotalaria juncea. Cientifica 42: 51-59.

DUARTE, RF; FERNANDES, LA; SAMPAIO, RA; SANTOS, LDT; GRAZZIOTTI, PH; SILVA, HP. 2013. Biomass yields, soil cover, content and accumulation of nutrients of some green manure legumes grown under conditions of north of Minas Gerais, Brazil. African Journal of Agricultural Research 8: 2430-2438.

EMBRAPA. Centro Nacional de Pesquisa de Solos. 1997. Manual de métodos de análise de solos. 2.ed. Rio de Janeiro. 212P.

FERMINO, MH; TRENTIN, AL; KÄMPF, AN. 2000. Caracterização física e química de materiais alternativos para composição de substratos para plantas: 1. Resíduos industriais e agrícolas. In: KÄMPF, NA; FERMINO, MH. (eds). Substratos para plantas: à base da produção vegetal em recipientes. Porto Alegre: Genesis. p.241-248.

FERNANDES, LA; VALADARES, RV; VALADARES, SV; RAMOS, SJ; COSTA, CA; SAMPAIO, RA; MARTINS, ER. 2013. Fontes de potássio na produtividade, nutrição mineral e bromatologia do maxixe do reino. Horticultura Brasileira 31: 607-612.

FERNANDES, LA; ALVES, DS; RAMOS, SJ; OLIVEIRA, FA; COSTA, CA; MARTINS, ER. 2005. Nutrição mineral de plantas de 
maxixe do reino. Pesquisa Agropecuária Brasileira 40: 719-722.

FORTE, A; FAGNANO, M; FIERRO, A. 2017. Potential role of compost and green manure amendment to mitigate soil GHGs emissions in Mediterranean drip irrigated maize production systems. Journal of Environmental Management 192: 68-78.

FUNGO, B; LEHMANN, J; KALBITZ, K; THIONGGO, M; TENYWA, M; OKEYO, I; NEUFELDT, H. 2019. Ammonia and nitrous oxide emissions from a field Ultisol amended with tithonia green manure, urea, and biochar. Biology and Fertility of Soils 55: 135-148.

GUEDES, RE; RUMJANEK, NG; XAVIER, GR; GUERRA, JGM; RIBEIRO, RLD. 2010. Consórcios de caupi e milho em cultivo orgânico para produção de grãos e espigas verdes. Horticultura Brasileira 28: 174-177.

LIMA, AS; TRANCOSO, FO; MOURA, KM; ALMEIDA, LB; SILVA, TNS; SOUZA, WM; MARCELLINI, OS. 2006. Caracterização centesimal de maxixe e sua aplicação na produção de picles. Alimentos Nutrição 17: 407-412.

MACCHIA, M; MONTORO, P; CECCARINI, L; MOLFETTA, I; PIZZA, C. 2009. Agronomic and phytochemical characterization of
Cyclanthera pedata Schrad. cultivated in central Italy. African Journal of Microbiology Research 3: 434-438.

MALAVOLTA, E; VITTI, CG; OLIVEIRA, SA. 1997. Avaliação do estado nutricional das plantas: princípios e aplicações. $2^{\mathrm{a}}$ ed. Piracicaba: Associação Brasileira para Pesquisa da Potassa e do Fosfato, 319p.

MIYAZAWA, K; MURAKAMI, T; TAKEDA, M; MURAYAMA, T. 2010. Intercropping green manure crops effects on rooting patterns. Plant and Soil 331: 231-239.

RIBEIRO JÚNIOR, JI. 2001. Análises estatísticas no SAEG. Viçosa: UFV, 2001. 301p.

SARMENTO, JJA; SANTOS, JJF; COSTA, CC; BOMFIM, MP. 2019. Agronomic performance of lettuce subjected to green manure with different leguminous species. Revista Brasileira de Engenharia Agrícola e Ambiental 23: 14-118.

SHARIFI, MZ; MATSUMURA, S; HIRASAWA, T; KOMA, TM. 2009. Apparent nitrogen mineralization rates of several green manures incorporated in soil and the application effects on growth of Komatsuna plants. Japanese Journal of Farm Work Research 44: 163-172.

TEIXEIRA, PC; DONAGEMMA, GK; FONTANA, A; TEIXEIRA, WG. 2017.
Manual de métodos de análise de solo. 3. ed. Brasília: Embrapa Informação Tecnológica. $573 \mathrm{p}$.

VALADARES, RV; DUARTE, RF; MENEZES, JBC; FERNANDES, LA; SANTOS, LDT; SAMPAIO, RA; MOTA, TC; ALMEIDA, RM. 2012. Fertilidade do solo e produtividade de milho em sistemas de adubação verde no norte de Minas Gerais. Planta Daninha 30: 505-516.

VALADARES, RV; ÁVILA-SILVA, L; TEIXEIRA, RS; SOUSA, RN; VERGÜTZ, L. 2016. Green manures and crop residues as source of nutrients in tropical environment. In: LARRAMENDY, M; SOLONESKI, S (eds). Organic fertilizers - from basic concepts to applied outcomes. London: INTECH p.51-84.

WEIH, M; ASPLUND, L; BERGKVIST, G. 2011. Assessment of nutrient use in annual and perennial crops: A functional concept for analyzing nitrogen use efficiency. Plant and Soil 339: 513-520.

ZHANG, X; ZHANG, R; GAO, J; WANG, X; FAN, F; MA, X; YIN, H; ZHANG, C; FENG, K; DENG, Y. 2017. Thirty-one years of rice-rice-green manure rotations shape the rhizosphere microbial community and enrich beneficial bacteria. Soil Biology and Biochemistry 104: 208-217. 